九州大学学術情報リポジトリ

Kyushu University Institutional Repository

\title{
Farming System in the Red River Delta with Special Emphasis on the Role of Dairy Production
}

\section{Chu Thi Kim Loan}

Laboratory of Agricultural Economics, Division of International Agricultural REsource Economics and BUsiness Administration, Department of Agricultural and Resoruce Economics, Graduate School of Bioresource and Environmental Sciences, Kyushu University

Yokogawa, Hiroshi

Laoratory of Agricultural Economics, Division of International Agricultural Resoruce Economices and Business Administration, Department o Agricultural and Resource Economics, Faculty of Agriculture, Kyushu University

\section{Kawaguchi, Tsunemasa}

Laoratory of Agricultural Economics, Division of International Agricultural Resoruce Economices and Business Administration, Department o Agricultural and Resource Economics, Faculty of Agriculture, Kyushu University

https://doi.org/10.5109/4556

出版情報：九州大学大学院農学研究院紀要. 48 (1/2)，pp.405-424，2003-10-01. Faculty of Agriculture, Kyushu University

バージョン：

権利関係: 


\title{
Farming System in the Red River Delta with Special Emphasis on the Role of Dairy Production
}

\author{
CHU Thi Kim Loan*, Hiroshi YOKOGAWA \\ and Tsunemasa KAWAGUCHI
}

\author{
Laboratory of Agricultural Economics, Division of International Agricultural Resource \\ Economics and Business Administration, Department of Agricultural and Resource \\ Economics, Faculty of Agriculture, Kyushu University, Fukuoka 812-8581
}

(Received June 30, 2003 and accepted July 15, 2003)

\begin{abstract}
Although potential exists, milk production in the Red River Delta (RRD) has met only less than 5 percent of the estimated demand for local consumption. The study thus conducted to unravel the underlying constraints. The specific objectives are (1) to examine farming and dairy production systems in the study areas and (2) to identify the factors affecting output of raw milk. These results were based on the data collected from 90 households in Hanoi and Hatay provinces. Descriptive statistics and production function analyses were used as the principal methods for data analysis. The findings show that although dairy farm was small in size, it was still a major component of the farming system. Feeding practice and raising costs were found to vary by breeds and households. Farmers could benefit from raising cows, but their net returns were only moderate. Lack of fodder, incidence of disease problem and low price of raw milk compared to input prices were main obstacles for extending the dairy farm size. The results of regression analysis indicate that farmers still can increase their milk output by using more some inputs (i.e. concentrated feed, fodder, labor).

The findings suggest that credit institutes should consider providing low and long-term loans to dairy farmers. Local leaders ought to pay attention on zoning of grass production and processing waste of dairy farms. In addition, the improvement of veterinary and milk collection networks at the raising zones is also very necessary. If the prices of milk and respective inputs are unchanged, the major productivity improvement must be rely heavily on raising high percentage $\mathrm{HF}$ blood cows (i.e. $3 / 4 \mathrm{HF}$ blood cows) and improving feed production.
\end{abstract}

\section{INTRODUCTION}

\section{Background}

Vietnam is an agricultural country with over 75 percent of the population living in and earning from the agricultural sector. Agriculture contributes around 25 percent of the total GDP (General Statistical Office, 2000). Animal husbandry, which is an integral part of the Vietnamese farming systems, contributes almost 19 percent to the total agricultural GDP (General Statistical Office, 2000). In recent years, agricultural production has been restructured in the direction of pushing animal husbandry as to make the animal branch become proportional to the cultivation sub-sector. The government's goal is to increase the contribution from the animal sub-sector to 45 percent-50 percent of the total agricul-

\footnotetext{
* Laboratory of Agricultural Economics, Division of International Agricultural Resource Economics and Business Administration, Department of Agricultural and Resource Economics, Graduate School of Bioresource and Environmental Sciences, Kyushu University.

+ Corresponding author (E-mail: chuloan@agr.kyushu-u.ac.jp)
} 
tural GDP by the year 2020 (Institution of Strategic Development, 1996).

The milk industry in Vietnam is being developed currently. After Vietnam changed to a market-oriented economy, dairy farming had more chances to develop due to the support of the government in terms of capital, technology, infrastructure, etc. Thus, both the population of cows and the quantity of raw milk have increased rapidly. In 1996, Vietnam produced almost 28 thousand tons of raw milk, but in 2002 that figure grew to some 90 thousand tons (Agricultural and Forestry Extension Center, 2002).

Some zones of the country, such as Lam Dong, Moc Chau (Son La province), Bavi (Hatay province), and the suburbs of Ho Chi Minh and Hanoi Cities have been evaluated as large potential areas for dairy farming. However, so far most cows are being reared in the South of Vietnam, particularly in suburbs of Ho Chi Minh City. In 1997, there were about 24,500 dairy cows in the country, over 80 percent of which were located in the South (Table 1).

Table 1. Cow population in different regions of Vietnam

\begin{tabular}{ccccc}
\multicolumn{1}{c}{} & \multicolumn{2}{c}{ (Unit: head) } \\
\hline Items & 1996 & 1997 & 2001 & 2002 \\
\hline Total cow population & 22,563 & 24,500 & 41,241 & 54,345 \\
Of which: - South of Vietnam* & 18,543 & 19,990 & 34,135 & 41,121 \\
& $(82.2)$ & $(81.6)$ & $(82.7)$ & $(75.7)$ \\
& 3,100 & 3,500 & 6,170 & 11,066 \\
- North of Vietnam* & $(13.7)$ & $(14.3)$ & $(15.0)$ & $(20.4)$ \\
\hline
\end{tabular}

Note: Numbers in parenthesis are percentages denoting structures of cow population according to different regions

Source: Agricultural and Forestry Extension Center, 1997 and 2002

Although there is a considerable progress, milk output in Vietnam is still too low compared with that of neighbor countries like China, Thailand and Indonesia (e.g., in 1997 the domestic milk production of Vietnam was abound 31 thousand tons, while this indicator of Thailand was 632 thousand tons-Chantalakhana and Skunmun, 2001). It satisfied only some10 percent of the national demand for dairy products in 2000 . The remainder came from importation. The development of dairy cow therefore is essential for Vietnam in order to increase domestic milk production to 20 percent by 2005 (Lich and Tuyen, 2002).

The Red River Delta is one of the regions that have the large potential for livestock breeding development. It has had high population density $\left(1,151\right.$ persons $\left./ \mathrm{km}^{2}\right)$, which implies large demand for milk (General Statistic Office, 2000). In addition, labor and feed are available. There were about 4 millions agricultural labors (around 25 percent of the country's agricultural labor total); 4,284 ha grass fields, and 23,937 ha mountainous and hill areas in the region (Kim, 1995). However, potentials for developing the raising activities have been exploited only at low level, especially for raising cows. According to Binnie

\footnotetext{
* Related to 7 agro-ecological regions of Vietnam, the North includes Red River Delta, Northern Mountainous and Middle Highlands, and Northern Central Coast. The South includes North-east of Southland and Mekong Delta.
} 
(1995), milk production in the Red River Delta remained very low and served only 4 percent of the estimated demand. More than $95 \%$ of milk consumed locally was produced in the South of Vietnam or imported.

Although potential exists, milk production in the RRD has not developed as fast as is generally expected. Thus, the study was conducted to contribute to explaining that situation.

\section{Objectives of the study}

The specific purposes are (1) to examine farming and dairy production systems in the study areas and (2) to identify the factors affecting output of raw milk with regard to different agro-economic zones.

\section{METHODOLOGY}

\section{Data collection}

To achieve the objectives, a number of relevant publications were collected and reviewed. In addition to the secondary data, primary data was also used to get more sufficient and accurate information. Before carrying out an actual survey, questionnaires were compiled after consultation with local leaders and experienced people. After that, preliminary testing of questionnaires was conducted in 10 households and necessary changes were made.

Formal survey using structured questionnaires was conducted to gather the major part of information needed to achieve the objectives of the study. The necessary data collected are farmer's general characteristics, dairy farm sizes and the structure of cow herds, feeding practices, cost and output of milk production, constraints on dairy farming, and sources of credit.

\section{Sampling technique}

The multi-stage random sampling method was administered in order to get representation from the region. First, provinces were selected based on their contributions to total milk production in the region. Hanoi and Hatay provinces were picked as representative of the region according to this basis. After that, one district having the highest cow population was chosen for each province. Second, from the selected districts, a random sampling method was used to select the farm households. The sample included 90 farm households, of which 50 farmers were located in Hanoi. Number of respondents in each location was selected according to proportion of the total households involving to milk production in the whole location.

\section{Data analysis}

Descriptive methods with contingency tables, diagrams and charts were used to achieve the first objectives. In addition, the quantitative analysis method was also applied to measure factors affecting milk output. Determinants of the production function included information of input utilization (the level of investment in concentrates, fodder feed and labor) and other information such as the types of breed, farm dairy size, educational level and dairy farm experience of the household heads. The form of Cobb-Douglas 
function was chosen to express this relationship.

Specifically, the Cobb-Douglas production function was expressed as follows:

$$
\begin{gathered}
Y=f(C o, F o, L a, E d, E x, F s, B r, D, u) \\
\text { or } \quad Y=a C O^{b l} F O^{b 2} L a^{b s} E d^{b 4} E x^{b 5} F s^{b 6} B r^{b 7} e^{b s D} e^{u}
\end{gathered}
$$

Where:

$Y=$ Total raw milk output of household per year $(\mathrm{kg} /$ household $/$ year)

$C o=$ Total expenditure on concentrates for milk cow(s) (thousand VND/household/year)

$F_{O}=$ Total cost of fodder fed for milk cow(s) (thousand VND/household/year).

$L a=$ Total labors taking care of milk cow(s) (man-day/household/year)

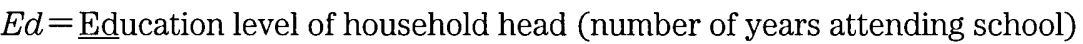

$E x=$ Experience in dairy farm of household head (number of years raising cow)

$F s=$ Dairy farm size (number of milk cows/household)

$B r=\underline{B r e e d}$ (average percentage of HF blood in milk cow herd of household)

$D=$ Regional dummy variable $(\mathrm{D}=1$ for Hanoi city and $\mathrm{D}=0$ for Hatay province)

$u=$ error term $\quad a, b_{i}=$ coefficients $\quad e=$ exponential indicator (2.71828).

Positive effects of all the variables (except for a dummy variable having either negative or positive sign) on milk output are expected in the model.

\section{BACKGROUND ON THE SAMPLED HOUSEHOLDS}

\section{General characteristics of the sample}

About 95 percent of the total household heads were in the active age group of 24 to 60 years and more than 90 percent of them had at least secondary education. Especially, 60 percent of the household heads in Hatay belonged to the 31-40 year group. This made its average age of Hatay household heads become younger than that of Hanoi's (Table 2). With respect to the dairy farm experience, Hanoi farmers have practiced raising cows for a longer time than Hatay farmers. However, raising cow is a still new occupation for both Hanoi and Hatay farmers.

\begin{tabular}{|c|c|c|c|c|c|}
\hline \multirow{2}{*}{ Items } & \multirow{2}{*}{ Unit } & \multicolumn{2}{|c|}{ Hanoi } & \multicolumn{2}{|c|}{ Hatay } \\
\hline & & Quantity & Percent & Quantity & Percent \\
\hline \multicolumn{6}{|l|}{ 1. Information related to household head } \\
\hline 1. 1. Average age & years & 44.3 & & 40.8 & \\
\hline 1. 2. Dairy farm experience & years & 5.7 & & 5.1 & \\
\hline 1.3. Average education level & years & 7.8 & & 7.4 & \\
\hline \multicolumn{6}{|l|}{ 2. Information related to household } \\
\hline 2.1. Household size & persons & 4.5 & 100.0 & 4.2 & 100.0 \\
\hline Of which, main laborer & persons & 2.7 & 60.0 & 2.2 & 52.4 \\
\hline 2.2. Total land & sao & 11.6 & 100.0 & 28.1 & 100.0 \\
\hline Of which, land used for growing grass & sao & 1.9 & 16.4 & 5.7 & 20.3 \\
\hline
\end{tabular}

Table 2. General characteristics of the sample

Source: Survey, 1999 (Note: $1 \mathrm{sao}=360 \mathrm{~m}^{2}$ ) 
The average household size of 4.5 persons was calculated for Hanoi, and 4.2 people for Hatay. In which, half of the members in the family were main laborers (the laborers are of working age). Being a hilly zone, Hatay farmers were assigned larger areas than Hanoi farmers. On average, a household located in Hatay held 28.1 sao $\left(10,116 \mathrm{~m}^{2}\right)$, while this indicator was only 11.6 sao $\left(4,176 \mathrm{~m}^{2}\right)$ in the case of Hanoi households. This is one of the reasons explaining why a part of larger area devoted for grass cultivation in Hatay.

\section{Structure of household income}

Household income consisted of both on-farm and off-farm incomes (Figure 1). However, the off-farm activities contributed a very small part to the total household income, i.e. it shared only 1.6 and 4.5 percent of the total income in Hatay and Hanoi, respectively. Despite being a hilly region, the average income of Hatay farmers did not differ from that of Hanoi farmers. This was largely because the households in Hatay used more land.

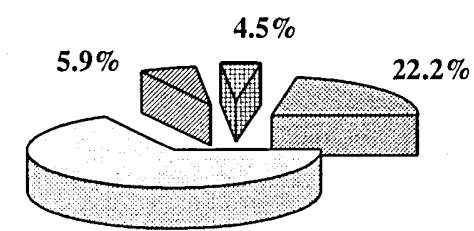

$67.4 \%$

Cultivation $\square$ Cow

Ⓞther animal 国Off-farm

Hanoi

Source: Survey, 1999

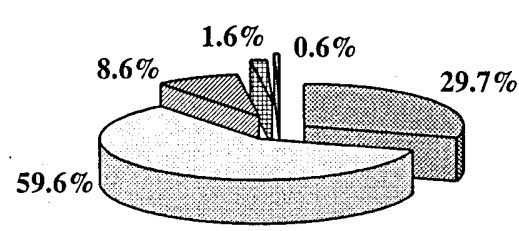

图 Cultivation $\square$ Cow

Other animal $\mathbf{\text { Off-farm }}$

$\square$ Planted forest

Fig. 1. The structure of households' income source

Raising cows was the main source of farm income, accounting for over 67 and 59 percent of household income in Hanoi and Hatay, respectively. Apart from the livestock raising, 100 percent of the interviewed dairy farmers also had crop cultivation activities. Those crops included paddy, corn, cassava, grass, and soybean, which generated from 22 to 29 percent of the total household income.

\section{FARMING SYSTEM OF THE STUDY AREAS}

Farming system of the study area was characterized by the integration of annual crops, cultivated fodder, livestock, trees and off-farm activities. Differing from others, grass production was also considered to be an important activity in the system. A farm household maneuvers those farming components with his/her management skill to extract output that can be generated from components. The preliminary interrelationship among them is expressed in Figure 2. 


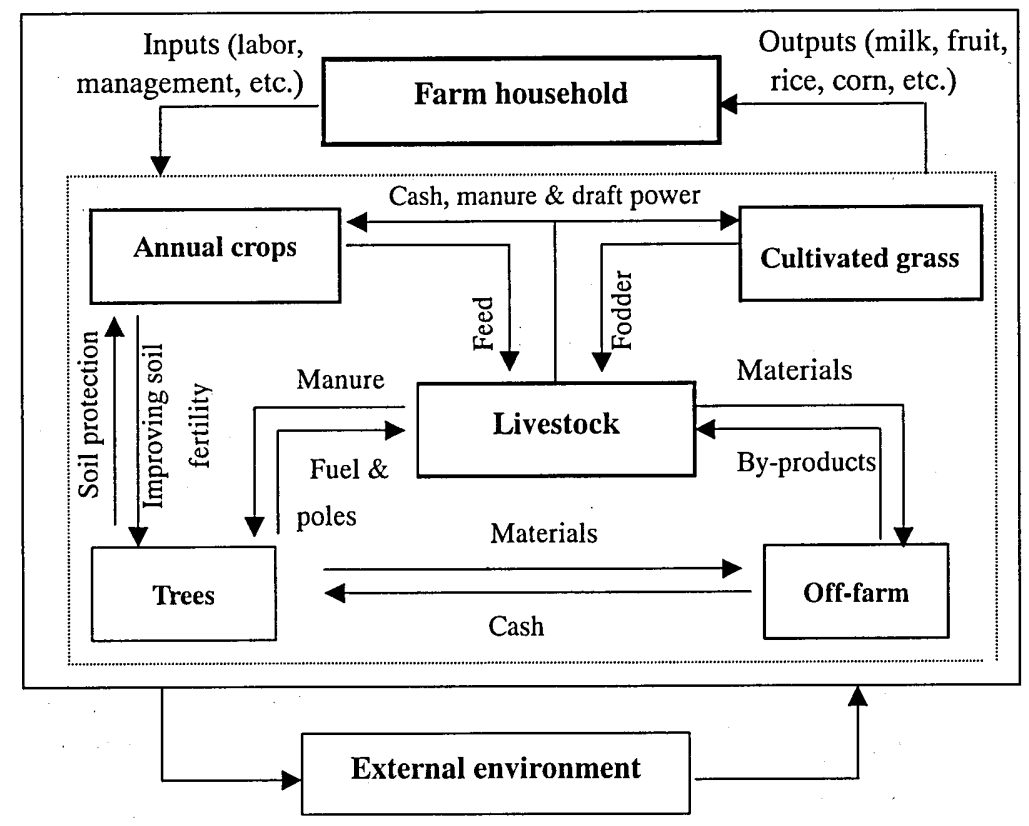

Fig. 2. Farming system of the study areas

To better understand the system, we will consider in detail each component and few external factors of the system.

\section{Annual crop and planted grass component}

Cropping pattern, which mainly included food crops like rice, corn, and cassava, were offered to provide food for home consumption and feed for livestock production.

The survey results showed that Hanoi farmers achieved rice yield of $175 \mathrm{~kg} / \mathrm{sao}$ and $154 \mathrm{~kg} / \mathrm{sao}$ in winter-spring season and summer season respectively, which was higher than Hatay farmers obtained. This could be explained by better production conditions in Hanoi. In comparison to the national level, crop yields in the study areas were higher. For example, the 1998 average rice yield of the nation was $140.4 \mathrm{~kg} / \mathrm{sao}$ (3.9 tons $/ \mathrm{ha}$ ) (General Statistical Office, 1999), which was $11.8 \mathrm{~kg} / \mathrm{sao}(0.3 \mathrm{tons} / \mathrm{ha}$ ) lower than that of the study areas. Abundant sources of manure resulting from cow raising largely explain the result. Because of available manure, the farmers rearing cows usually applied higher amounts of manure than other farmers did.

In addition to rice, corn was a common crop in the Hanoi cropping sub-system. All Hanoi sample households cultivated corn, and the average area under maize per household accounted for a greater area than that of rice. Regarding Hatay, around 30 percent of the total interviewed farmers produced corn. Average corn yield varied by both season and location. Since corn cultivation in Hatay was done under poorer environmental conditions (slope soil, lack of irrigation, etc.), the production per unit area seemed relatively 
low. Hatay farmers only obtained $88.7 \mathrm{~kg}$ of corn per sao in spring season, which was about $42.6 \mathrm{~kg}$ lower than that of Hanoi farmers. However, average yield of corn in the study area was still higher when compared to the national level. Based on statistical yearbook 1998, average corn yield of the country was $89.2 \mathrm{~kg} / \mathrm{sao}(2.5$ tons $/ \mathrm{ha}$ ), which was $30.1 \mathrm{~kg} / \mathrm{sao}$ lower than that of the region studied.

Instead of corn, cassava was a common crop in Hatay with an average yield of $370 \mathrm{~kg} / \mathrm{sao}$. Most of the Hatay farmers planted cassava in a relatively large area (about 8.5 sao per household). On average, the annual output of cassava per interviewed household was over $3,100 \mathrm{~kg}$.

Table 3. Average area, yield and output of major crops

\begin{tabular}{|c|c|c|c|c|c|c|c|c|}
\hline \multirow[b]{2}{*}{ Crops } & \multicolumn{4}{|c|}{ Hanoi } & \multicolumn{4}{|c|}{ Hanoi } \\
\hline & $\begin{array}{c}\% \text { of } \\
\text { tot.hh }\end{array}$ & $\begin{array}{l}\text { Area* } \\
\text { (sao) }\end{array}$ & $\begin{array}{c}\text { Yield } \\
(\mathrm{kg} / \mathrm{sao})\end{array}$ & $\begin{array}{l}\text { Output* } \\
\text { (kg/hh) }\end{array}$ & $\begin{array}{c}\% \text { of } \\
\text { tot.hh }\end{array}$ & $\begin{array}{l}\text { Area } \\
\text { (sao) }\end{array}$ & $\begin{array}{c}\text { Yield } \\
(\mathrm{kg} / \mathrm{sao})\end{array}$ & $\begin{array}{l}\text { Output* } \\
\text { (kg/hh) }\end{array}$ \\
\hline Spring rice & 98.0 & 4.2 & 174.9 & 742.9 & 75.0 & 5.2 & 152.8 & 793.1 \\
\hline Summer rice & 98.0 & 4.2 & 154.2 & 654.9 & 70.0 & 5.8 & 129.1 & 749.6 \\
\hline Winter corn & 100.0 & 4.9 & 117.2 & 571.2 & 22.5 & 0.9 & 88.7 & 82.8 \\
\hline Spring corn & 100.0 & 4.9 & 131.3 & 640.1 & 37.5 & 1.5 & 97.9 & 146.6 \\
\hline Cassava & - & - & - & - & 95.0 & 8.5 & 369.9 & $3,135.9$ \\
\hline Fodder & 52.0 & 1.9 & $6,588.7$ & 12,782 & 97.5 & 5.7 & 6,022 & 34,308 \\
\hline
\end{tabular}

Note: "\% of tot.hh" denotes percentage of the total interviewed household.

* Area and output were the means based on the total interviewed households

Source: Survey, 1999

As mentioned above, raising cow was the main source of household income. Moreover, it also generated cash flow regularly for dairy farmers. Thus, fodder production that was derived from the demand of the cow sector became an important activity in the system. About 97 percent of the total households in Hatay grew grass with an average area of 5.7 sao per household. The survey revealed that almost all Hatay farmers had enough cultivated fodder to feed their cows. However, only 52 percent of the total sample households in Hanoi allocated their land for growing fodder. Grass output cultivated by one Hanoi household was only enough to feed her/his cows in four months of the year. The rest came from other activities such as collecting and buying. While there was not a formal market for grass, the above characteristic show a obstacle in the procedure of cow herd development in Hanoi.

\section{Livestock component}

Livestock (particularly cows and pigs) were the main source of cash for all of the interviewed households. The average number of pigs per household was 1.1 head and 1.6 head in Hanoi and Hatay, respectively. In general, the growth of pig production was not high since the farmers only attempted to make use of home left-over food to feed them. About 82.5 percent of the sample households in Hatay owned pigs, while that number was lower in Hanoi (Table 4).

Poultry was usually kept in the backyard of the farmers' homestead as scavengers. 
Table 4. Dominant livestock types in the study areas

\begin{tabular}{lccccc}
\hline \multirow{2}{*}{$\begin{array}{c}\text { Livestock } \\
\text { species }\end{array}$} & \multicolumn{3}{c}{ Hanoi } & & \multicolumn{2}{c}{ Hatay } \\
\cline { 2 - 3 } \cline { 5 - 6 } & \% of hh & $\begin{array}{c}\text { Average number of } \\
\text { owning }\end{array}$ & & $\begin{array}{c}\text { \% of h.h } \\
\text { heads in a household* }\end{array}$ & $\begin{array}{c}\text { Average number of } \\
\text { heads in a household* }\end{array}$ \\
\hline 1. Pig & 54.0 & 1.10 & 3.66 & 82.5 & 1.60 \\
2. Cow & 100.0 & 3.06 & & 100.0 & 4.15 \\
3. Poultry & 22.0 & 0.14 & & 55.0 & 22.75 \\
4. Buffalo & 14.0 & & & 52.5 & 0.53 \\
\hline
\end{tabular}

Note: *The numbers were means based on the total interviewed households

Source: Survey, 1999

Due to having the advantage of a larger homestead area, the number of households owning poultry in Hatay was much higher than that of Hanoi. Only 22 percent of the total sample households in Hanoi raised poultry, while that figure was 66 percent in the case of Hatay. Poultry production was mostly used for meat and eggs, which largely served for home consumption.

With the purpose of investigating the situation of dairy production in the RRD, the households owning at least one cow were interviewed. Most Hanoi farmers spent some hours pasturing their cows on the dyke of Red River. Meantime, Hatay farmers applied a confinement system, which was located in the same area as their houses. Buffalos are mainly raised for providing draft power. Due to having easier access to service of land preparation, Hanoi farmers did not trend to keep buffalo. Only 14 percent of the total interviewed farmers owned them.

\section{Planted forestry and fruit trees}

Forest production in the study area was small. The amount marketed was not ascertained. Acacia auriculiformis, Acacia mangium and Eucalyptus cammaldulensis are forestry trees that were popularly planted in the region, mainly under the grant of World Food Program (in Vietnam it is called PAM in French).

Major fruit trees in the region were banana, papaya, pineapple, longan, mango, and litchi. Most of them were grown on the homestead garden in a small piece of land. There were only 3.3 percent of the total sample households having over 1 sao of fruit trees. Except for some traditional fruit species, such as banana, papaya, and pineapple, fruit cultivation was concentrated in the large farms. Although fruit trees did not generate high income, they played an important role in supplementing nutrition for the farmers in the study areas.

\section{Off-farm activities}

Off-farm activities in the study areas were rather diverse. They were rice milling, wine making, handicraft, small trading, employees and services. The survey revealed that there were 23.3 percent of the total sample households having extra income from off-farm activities. 


\section{External environment}

External factors, such as government policies, institutional organizations, infrastructure networks are important for the smooth and viable existence of the farming system. As mentioned, raising cow requires a high level of investment in both capital and management. Hence, accessibility to credit and to technological information is significant for enhancing the production. This part gives a brief description of two these issues.

\section{Access to credit}

Most farmers in the study area needed to borrow money to operate their farms because they could not afford the high capital investment during establishment of the farms. The survey showed that farmers could borrow money from two available credit sources, namely formal and informal sources. In which, formal sources included agricultural banks, women associations, and milk processing factories that provided larger loans (Tables 5 and 6). There were 32.1 percent and 47.2 percent of the total borrowers in Hanoi and Hatay, respectively borrowing money from agricultural banks at an interest rate of 1.2 percent per month. Some other state organizations like women associations, centers of extension lend to farmers at the lower rate of interest (0.6-0.8 percent per month). However, it was still difficult for the farmers to obtain credit from those organizations due to complicated lending procedures, inadequate assets to meet collateral requirement, etc.

Informal sources such as village lenders, relatives, friends, etc. were also important

Table 5. Farmers' access to credit in Hanoi

\begin{tabular}{lcccc}
\hline \multicolumn{1}{c}{ Sources } & $\begin{array}{c}\text { \% of total } \\
\text { borrowers }\end{array}$ & $\begin{array}{c}\text { Amount borrowed } \\
\text { (million VND)* }\end{array}$ & $\begin{array}{c}\text { Interest rate } \\
(\% / \text { month) }\end{array}$ & $\begin{array}{c}\text { Duration } \\
\text { (month) }\end{array}$ \\
\hline 1. Friends & 3.6 & 3.0 & 0.0 & No limited \\
2. Village lenders & 10.7 & 6.0 & 2.0 & No limited \\
3. Relatives & 14.3 & 7.0 & & \\
-Relatives 1 & 76.7 & 9.0 & 0.4 & 24.0 \\
-Relatives 2 & 23.3 & 5.0 & 0.0 & No limited \\
4. Women associations & 35.7 & 5.0 & 0.6 & 24.0 \\
5. Agricultural banks & 32.1 & 6.3 & 1.2 & 20.5 \\
7. Other & 3.6 & 10.0 & 0.2 & No limited \\
\hline
\end{tabular}

Source: Survey, 1999

Table 6. Farmers' access to credit in Hatay

\begin{tabular}{lcccc}
\hline \multicolumn{1}{c}{ Sources } & $\begin{array}{c}\text { \% of total } \\
\text { borrower }\end{array}$ & $\begin{array}{c}\text { Amount borrowed } \\
\text { (million VND) }\end{array}$ & $\begin{array}{c}\text { Aver. interest } \\
\text { rate (\%/month) }\end{array}$ & $\begin{array}{c}\text { Duration } \\
\text { (month) }\end{array}$ \\
\hline 1. Village lenders & 5.5 & 3.0 & 1.7 & 18.0 \\
2. Relatives & 2.8 & 4.0 & 1.0 & No limited \\
3. Milk factories & 41.7 & 5.0 & 0.0 & 12.0 \\
4. Agricultural banks & 47.2 & 6.6 & 1.2 & 28.4 \\
5. Others & 2.8 & 5.0 & 0.8 & 24.0 \\
\hline
\end{tabular}

Note: Average amount of borrowed = (Total loan/Number of borrowers in each category)

Source: Survey, 1999 
for farmers, because they could get credit easier than that from the formal sources. Those individuals do not require complicated procedures to lend money. The survey revealed that most of the farmers who borrowed money from their relatives paid no or low interest rate, i.e. 0 or 1 percent per month. About 14.3 percent of the total borrowers in Hanoi fell under this group. Note that 10.7 percent and 5.5 percent of the total borrowers in Hanoi and Hatay, respectively did not have opportunities to get access to formal sources. They had to borrow money from village lenders at high rate of interest (i.e. 2 percent per month).

Hatay farmers were said to have easier access to credit than Hanoi farmers. If a Hatay farmer wants to buy a dairy cow to raise, he/she can borrow 5 million VND/cow from the milk-processing factory at 0 percent interest rate (in the first year). The repayment will be deducted every month from the quantity of raw milk that farmers have to sell to the factory. However, the farmers still have difficulty buying and raising cows, because the amount of money borrowed from the factory was not high enough to buy a cow (at survey period they need about 10 million VND to buy a milk cow). Moreover, they became dependent on the factory.

\section{Access to information}

The survey showed that co-farmers (i.e. neighbors, friends, etc), agricultural extension officials, and the mass media were common sources of information for farmers concerning production technology. Farmers in the study areas had chances to get access to new technologies through participation in training courses held by extension centers. However, the training courses were not organized regularly, so main information sources for farmers were still their co-farmers (Tables 7 and 8)

Table 7. Ranking sources of technological information by Hanoi farmers

\begin{tabular}{lrrrc}
\hline \multirow{2}{*}{ Sources } & \multicolumn{2}{c}{ Percentage of farmers responses with priorities } & \multirow{2}{*}{ Total } \\
\cline { 2 - 4 } & $1^{\text {st }}$ & $2^{\text {nd }}$ & $3^{\text {rd }}$ & score \\
\hline Co-farmers & 58 & 40 & 2 & 128 \\
Extension officials & 32 & 36 & 24 & 96 \\
Mass media & 10 & 24 & 48 & 63 \\
Others & 0 & 0 & 26 & 13 \\
\hline
\end{tabular}

Source: Survey, 1999

Table 8. Ranking sources of technological information by Hatay farmers

\begin{tabular}{lrrrr}
\hline \multirow{2}{*}{ Sources } & \multicolumn{2}{c}{ Percentage of farmers response with priorities } & \multirow{2}{*}{ Total } \\
\cline { 2 - 4 } & $1^{\text {st }}$ & $2^{\text {nd }}$ & $3^{\text {rd }}$ & score \\
\hline Co-farmers & 77.5 & 20.0 & 2.5 & 110 \\
Extension officials & 15.0 & 47.5 & 27.5 & 67 \\
Mass media & 7.5 & 27.5 & 57.5 & 54 \\
Others & 0 & 5.0 & 12.5 & 9 \\
\hline
\end{tabular}

Note: First to third under percentage of farmers indicates farmers' ranks to respective sources. To calculate total score, first was accorded 3 score and third equals 1 score

Source: Survey, 1999 


\section{DAIRY PRODUCTION SYSTEM}

\section{Dairy farm size}

The distribution of herd size for the interviewed farmers in the study areas is shown in Table 9. Most of the dairy herds were small ( 1 or 2 heads of cows per household) and medium (from 3 to 5 heads) in size. The number of households having the size of $3-5$ heads accounted for almost 50 percent of the total interviewed households for both locations. There were only a few farmers having the large herd size of over 10 cows. Evidence shows that about 2 percent and 7.5 percent of the total households in Hanoi and Hatay, respectively fall under this category.

Table 9. Size distribution of farm households in the study areas

\begin{tabular}{lrrrrr}
\hline \multirow{2}{*}{ Farm size } & \multicolumn{3}{c}{ Hanoi } & & \multicolumn{2}{c}{ Hatay } \\
\cline { 2 - 3 } \cline { 5 - 6 } & No. of hh & Percent & & No. of hh & Percent \\
\hline From 1 to 2 heads & 17 & 34.0 & 13 & 32.5 \\
From 3 to 5 heads & 24 & 48.0 & 20 & 50.0 \\
From 6 to 10 heads & 8 & 16.0 & 4 & 10.0 \\
Greater 10 heads & 1 & 2.0 & 3 & 7.5 \\
\hline
\end{tabular}

Source: Survey, 1999

\section{Structure of cow herd in the interviewed households \\ The kinds of breed in different agro-ecological regions}

According to each of the ecological, economical, and rearing conditions, the different crossing formulas are being applied in Vietnam. For example, crossbreeds of 3/8, 1/2 and $3 / 4$ blood of Holstein Friesian (HF) are suitable for the RRD, while the crossbreeds of $3 / 4$ and 7/8 of HF blood are adopted in the areas of Ho Chi Minh, Tien Giang, and Long An provinces. The regions of Moc Chau and Lam Dong where annual average temperature is much lower could rear the dairy cows of higher HF blood. (Vang,1998).

Based on the survey, there were four common types of cow breed raised by the households in the study areas. They are the crossbreeds of Red Sindhi, 1/2 HF blood, 3/4 $\mathrm{HF}$ blood and 3/8 HF blood. Except for Sindhi crossbred cows, most of HF crossbred cows in the region were the results of crossing among 3 bloodlines: domestic, Red Sindhi and HF blood. For example, the $1 / 2 \mathrm{HF}$ blood cow had 50 percent of HF blood, 25 percent of Red Sindhi blood and 25 percent of domestic blood.

\section{Structure of cow herd}

In Hanoi each household owned an average 3.66 heads of cows, of which milking cows constituted 57.4 percent (Table 10). The remaining percentage fell under both maiden heifers and heifer calves. As classified according to kinds of breed, most cows raised in the household were the $3 / 4 \mathrm{HF}$ blood cows, which contributed to 67.2 percent of the cow population. Some breeds having a lower yield like the crossbreeds of Red Sindhi and 3/8 HF blood were not adopted broadly by Hanoi farmers. They accounted for only 7.1 percent of total herd numbers.

The average size of holding of 4.15 cows per household was calculated for Hatay. 
Table 10. Structure of cow herd in sample households

\begin{tabular}{lrrrrrr}
\hline \multirow{2}{*}{ Classified criteria } & \multicolumn{2}{c}{ Hanoi } & & \multicolumn{2}{c}{ Hatay } \\
\cline { 2 - 3 } \cline { 5 - 6 } 1. By age & Head & Percent & & Head & Percent \\
- Heifer calves & 183 & 100.0 & & 166 & 100.0 \\
- Maiden heifers & 45 & 24.6 & & 28 & 16.9 \\
- Milking cows & 33 & 18.0 & & 52 & 31.3 \\
2. By breed & 105 & 57.4 & & 86 & 51.8 \\
- 1/2 HF blood crossbred cows & 183 & 100.0 & & 166 & 100.0 \\
-3/4 HF blood crossbred cows & 123 & 25.7 & & 66 & 39.8 \\
- 3/8 HF blood crossbred cows & 5 & 67.2 & & 71 & 42.8 \\
- Sindhi crossbred cows & 8 & 2.7 & & 18 & 10.8 \\
\cline { 6 - 7 } & & 4.4 & & 11 & 6.6 \\
\hline
\end{tabular}

Source: Survey, 1999

Over half of them were milking cows. Percentage of maiden heifers raised in Hatay was much higher than that of Hanoi accounting for 31.3 percent of total cow population. This was largely explained by the formation of a milk-processing factory in 1997, which encouraged the farmers to raise cows in the previous years. Differing from Hanoi farmers, the households in Bavi applied both the crossbreeds of 1/2 HF blood and 3/4 HF blood as main breeds. Moreover, the Sindhi crossbred cow and 3/8 HF blood cow have also received their interest. It was found that in this region about 17.4 percent of the cow population fell under these breed categories.

\section{Feeding practices in the study areas}

The dairy farmers in the study area indicated that when feeding their cows, they considered the stages of lactation and physiological characteristics of the cow. Thus, the feeding regime of milk cows was different between the milking period and the dry-off period

In lactation period, the cows received mixed rations including roughage and concentrates. Of which, concentrated feed was made of corn meals, cassava meals, rice bran, soybean meals, fish meals, etc. To mix among them, the introduced structure was $40 \%$, $20 \%, 20 \%, 12 \%, 4 \%, 2 \%$ and $2 \%$ of corn meals, cassava meals, rice bran, soybean meals, fish meals, mineral and salt, respectively (Thuong, 1998). However, in practice farmers fed their cows at different ratios based on their experience and perception as well as availability of feed. Most farmers in the study area fed concentrates to a cow according to her milk yield. For example, when a milking cow produced $10 \mathrm{~kg}$ of milk per day the farmers fed $3-4 \mathrm{~kg}$ of concentrate feed. Some other households based on age, and breed of the cow. Level of feeding was found to vary by farmers and by types of breed. Averages of investment on feed per day for selected cow groups in the milking period are illustrated in Table 11.

In general, the crossbreeds of $3 / 4 \mathrm{HF}$ blood and $1 / 2 \mathrm{HF}$ blood require higher levels of feeding than other breeds. The finding indicated that on average, one F2 milking cow was fed $1.27 \mathrm{~kg}$ of rice bran, $2.78 \mathrm{~kg}$ of corn meals, and $5.36 \mathrm{~kg}$ of brewery's by-product, etc. per milking day by Hanoi farmers. While amounts of rice bran, corn meals, and brewery's 
Table 11. Feed constituents for selected milking cow groups

\begin{tabular}{|c|c|c|c|c|c|c|}
\hline & & & & & it: $\mathrm{kg} / \mathrm{de}$ & ow) \\
\hline \multirow{2}{*}{ Items } & \multicolumn{3}{|c|}{ Hanoi } & \multicolumn{3}{|c|}{ Hatay } \\
\hline & F2 cow & F1 cow & SC cow & F2 cow & Fl cow & SC cow \\
\hline 1. Rice bran & 1.27 & 1.22 & 0.95 & - & - & - \\
\hline 2. Whole rice meals & - & - & - & 0.93 & 0.89 & 0.81 \\
\hline 3. Cassava meals & - & - & - & 1.28 & 1.34 & 1.01 \\
\hline 4. Corn meals & 2.78 & 2.38 & 1.90 & 1.69 & 1.21 & 0.89 \\
\hline 5. Brewery's by-products & 5.36 & 4.87 & 3.06 & 3.48 & 2.38 & 2.00 \\
\hline 6. Soybean meals & 0.26 & 0.21 & 0.15 & 0.29 & 0.24 & 0.13 \\
\hline 7. Mineral & 0.05 & 0.05 & 0.03 & 0.06 & 0.05 & 0.03 \\
\hline 8. Salt & 0.06 & 0.05 & 0.04 & 0.07 & 0.06 & 0.03 \\
\hline 9. Fish meals & 0.19 & 0.10 & 0.04 & 0.20 & 0.17 & 0.10 \\
\hline 10. Green fodder & 28.25 & 27.16 & 25.00 & 32.75 & 31.16 & 28.75 \\
\hline 11. Dry fodder & 1.58 & 1.65 & 1.44 & 1.48 & 1.43 & 1.56 \\
\hline
\end{tabular}

Note: $\mathrm{F} 2$ and $\mathrm{F} 1$ cows denote $3 / 4 \mathrm{HF}$ blood and $1 / 2 \mathrm{HF}$ blood crossbred cows, respectively SC stands for Sindhi crossbred.

Source: Survey, 1999

by-product fed to Sindhi crossbred cow were $0.95,1.90$ and $3.06 \mathrm{~kg}$, respectively. Moreover, HF crossbred cows were also fed higher amount of mineral, soybean meals, etc. The same tendency was found in Hatay where the farmers usually used rice meals and cassava meals to substitute for corn meals or rice bran. Apart from concentrates, the cows also required certain quantities of fodder for body maintenance and growth. This amount varied by locations as well as by the kinds of breed. The Hanoi farmers fed from 25 to $29 \mathrm{~kg}$ of green fodder and 1.4 to $1.7 \mathrm{~kg}$ of dry fodder for a milking cow per day, which was lower than the feeding level of Hatay farmers.

In the dry-off period, the level of feeding was lower than that of the milking period. The farmers fed from 1 to $2 \mathrm{~kg}$ of concentrates to a cow per day depending on types of breed. Constituents of the ration normally included corn meals, rice bran or cassava meals, salt, mineral and fodder. Very few households used soybean meals and brewery's by-product to feed dry cows.

\section{Average milk yield in a milking cycle of 10 months}

Milk yield varied by kinds of cow breed. The survey indicated that $3 / 4 \mathrm{HF}$ blood cow gave the highest yield, followed by crossbreeds of $1 / 2 \mathrm{HF}$ blood, $3 / 8 \mathrm{HF}$ blood and Sindhi. On average, milk yield per $3 / 4 \mathrm{HF}$ blood cow in a milking cycle of 10 months was $3,409.6 \mathrm{~kg}$, while this indicator reduced to $2,399.8 \mathrm{~kg}$ in the case of Sindhi crossbred cow. The crossbreeds of $1 / 2$ and $3 / 8 \mathrm{HF}$ blood had medium milk yields of $3,065.4$ and $2,848.5 \mathrm{~kg}$, respectively.

\section{Costs of milk production}

In recent years, demand for milk and milk products has been rapidly increased due to population growth, urbanization and increases in the level of income. This encouraged the farm households to enter dairy farming. Having different rearing conditions, so farm- 
ers selected different kinds of cow breed to raise. In this part, production costs are discussed according to three major types of breed, namely the Sindhi crossbred, 1/2 and $3 / 4 \mathrm{HF}$ blood cows. The cost of milk production for the $3 / 8 \mathrm{HF}$ blood cow is not presented here because of its small sample size. The results are illustrated in Table 12.

Table 12. Costs of milk production according to different types of breed (Unit: '000 VND/cow/year)

\begin{tabular}{|c|c|c|c|c|c|c|}
\hline \multirow{2}{*}{ Items } & \multicolumn{3}{|c|}{ Hanoi } & \multicolumn{3}{|c|}{ Hatay } \\
\hline & SC cow & F1 cow & F2 cow & SC cow & F1 cow & F2 cow \\
\hline 1. Variable costs & $6,770.9$ & $8,364.7$ & $9,204.2$ & $5,962.3$ & $7,233.3$ & $8,118.8$ \\
\hline 2. Fixed costs & $1,592.1$ & $1,811.5$ & $2,007.0$ & $1,603.7$ & $2,049.9$ & $2,210.9$ \\
\hline 3. Total costs & $8,363.0$ & $10,176.2$ & $11,211.2$ & $7,566.0$ & $9,283.2$ & $10,329.7$ \\
\hline $\begin{array}{l}\text { 4. Cost per kg of milk } \\
\text { (VND } / \mathrm{kg})\end{array}$ & $3,119.0$ & $2,934.0$ & $2,829.3$ & $2,849.3$ & $2,640.8$ & $2,603.6$ \\
\hline $\begin{array}{l}\text { 5. Average selling prices } \\
\text { (VND/kg) }\end{array}$ & & $3,102.7$ & & & $2,803.5$ & \\
\hline
\end{tabular}

Note: $\mathrm{F} 2$ and F1 cows denote $3 / 4 \mathrm{HF}$ blood and 1/2 HF blood crossbred cows, respectively.

SC stands for Sindhi crossbred.

Exchange rate of VND per dollar at the survey period was 12,500 VND.

To calculate above items, a number of family inputs (i.e. corn meals, cultivated grass) were supposed to be purchased at market prices.

Source: Survey, 1999

Commonly, the higher percentage of HF blood the cows have, the higher level of investment they require. Total cost of raising a Sindhi crossbred cow per year in Hanoi was 8.4 million VND, while this figure reached to 11.2 million VND in case of an F2 cow. The cost per $\mathrm{kg}$ of milk was quite high for raising the Sindhi crossbred cow. It reached 3,119 and 2,849 VND per kg of milk in Hanoi and Hatay, respectively, which was slightly higher than average selling prices. Thus, farmers only could benefit from raising a SC cow when their labor forces and other resources were idle and abundant. Generally speaking, production costs in Hanoi were assessed to be higher than those in Hatay, i.e. variable costs for raising a F1 cow in Hanoi were almost 8.4 million VND, being 1.1 million VND higher than the item of Hatay. This was largely due to a higher labor cost incurred by Hanoi farmers. They spent few hours grazing the cow on the dyke of the Red River, so their labor cost was higher than that of Hatay farmers who applied form of confinement. Comparison between the costs per kg of milk and average selling prices indicate that with existing pricing method, raising the $\mathrm{F} 2$ cow was better in terms of benefit than raising other breeds.

\section{Marketing of raw milk Quantities of raw milk marketed}

Less than 2 percent of the total milk output was used for home consumption. The remaining amount was sold to different buyers (Table 13). In Hanoi, the main flows of raw milk were from farmers to cooperative and to collectors, which accounted for 
40.5 percent and 48.5 percent of the total sold volume, respectively. There were few farmers delivering their milk directly to the processing factory. Contrary to the Hanoi case, the flow of milk materials to the processing factory in Hatay accounted for 46.4 percent of the total sold amount. This may be largely explained by the fact that Nestle' Milk Factory set up milk collection stations at communes which helps farmers easier sell milk materials to. Bavi Collection Station that belongs to Center of Bavi Cow and Grass-field Research played the most important role in buying raw milk from Hatay farmers with the ratio of 49.2 percent.

Table 13. Quantities of raw milk marketed according to different buyers

\begin{tabular}{lrrrrr}
\hline \multirow{2}{*}{ Buyers } & \multicolumn{2}{c}{ Hanoi } & & \multicolumn{2}{c}{ Hataya } \\
\cline { 2 - 3 } \cline { 5 - 6 } \cline { 5 - 6 } Quantity (kg) & Percent & & Quantity (kg) & Percent \\
Collection Co-operative & 139,240 & 40.52 & & - & - \\
Fresh milk shops & 34,897 & 10.16 & & 11,572 & 4.37 \\
Hanoi Milk Factory & 2,443 & 0.71 & & - & - \\
Collectors & 166,809 & 48.54 & & - & - \\
Final consumers & 244 & 0.07 & & 135 & 0.05 \\
Bavi Collection Station & - & - & & 130,202 & 49.20 \\
Nestle Milk Factory & - & - & & 122,721 & 46.38 \\
$\quad$ Total & $\mathbf{3 4 3 , 6 3 4}$ & $\mathbf{1 0 0 . 0 0}$ & & $\mathbf{2 6 4 , 6 3 0}$ & $\mathbf{1 0 0 . 0 0}$ \\
\hline
\end{tabular}

Source: Survey, 1999

\section{Price and quality of raw milk}

Milk price was pre-determined based on its quality criteria. As showed in Table 13, some buyers like collectors, the milk collection co-operative, the Bavi station, and Nestle Milk Factory used the same quality criteria to buy raw milk. Every morning and afternoon, usually before 8 o'clock (a.m.) and 6 o'clock (p.m.) farmers deliver their milk to the collecting points. Raw milk will be checked by simple quality tests, such as organoleptic tests (smell, appearance, taste), alcohol test and lactometer test (for determining specific gravity of the milk). However, the most important criterion for pricing was the specific gravity of milk. The highest prices were $3000 \mathrm{VND}$ and $3150 \mathrm{VND}$ per $\mathrm{kg}$ calculated for

Table 14. Buying price levels and farmers' quality practice at collection points

\begin{tabular}{lccccccc}
\hline \multicolumn{2}{c}{ Items } & Grade A & Grade B & Grade C & Grade D & Grade E & Grade F \\
\hline $\begin{array}{l}\text { 1. Specific } \\
\text { gravity }\end{array}$ & $>1.0321$ & $1.0301-1.0320$ & $1.0281-1.0300$ & $1.0261-1.0280$ & $1.0241-1.0260$ & $<1.0240$ \\
2. Price levels (VND/kg) & & & & & & \\
+ In Hanoi & 3150 & 3100 & 3000 & 2900 & 2700 & 2600 \\
+ In Hatay & 3000 & 2800 & 2700 & 2600 & 2500 & 2400 \\
3. Farmers' quality practice (\%) & 83.7 & 10.0 & 0.6 & - & - \\
+ In Hanoi & 5.7 & 8.1 & 9.1 & 0.7 & - & - \\
+ In Hatay & 6.1 & 84.1 & & & & - \\
\hline
\end{tabular}

Source: Survey, 1999 
raw milk with the grade A in Hatay and Hanoi, respectively (Table 14). Around 84 percent of the total marketed milk amount belonged to grade $\mathrm{B}$, which has the price levels of 2800 VND and 3100 VND per $\mathrm{kg}$ in Hatay and Hanoi, respectively. The amount of raw milk having grade A constituted only around 6 percent of the total marketed milk amount.

When selling to Hanoi Milk Factory, farmers encounter a strict test of milk quality. The milk has to satisfy criteria of organoleptic, chemical-physical components, and microorganism. The test usually takes for hours. The stricter test is one of main reasons to explain why a few Hanoi farmers deliver their milk directly to the factory. The highest price offered by the factory for the raw milk meeting all the criteria was $3550 \mathrm{VND}$ per $\mathrm{kg}$, but farmers got only around $3100 \mathrm{VND}$ due to lower quality.

Fresh milk shops are said to be an attractive market for both farmers and intermediary agents. The owners of shops usually bought higher prices than the factories. Moreover, they did not check for the criteria of microorganism as well as chemical-physical components of raw milk. Commonly, only sensory evaluation is implemented by them. The survey results indicated that the price of raw milk at this market ranged from 3,500 to $4,800 \mathrm{VND} / \mathrm{kg}$ varying by shop and season. Although price of raw milk at the fresh milk shops was usually higher, amount of raw milk demanded by them was small, especially in winter. Therefore, it was not easy for every farmer to enter this market.

\section{Profitability of milk production}

Gross revenue received by a Hanoi farmer was 11.4 million VND, which was higher than that of a Hatay farmer (Table 15). This was largely due to a lower price of raw milk paid to Hatay farmers.

Table 15. Economics of raising a milk cow

\begin{tabular}{lrr} 
& \multicolumn{1}{c}{ (Unit: '000 VND/year/cow) } \\
\hline \multicolumn{1}{c}{ Items } & \multicolumn{1}{c}{ Hanoi } & Hatay \\
\hline 1. Gross revenue: & $11,418.0$ & $9,927.1$ \\
2. Total variable costs & $8,751.2$ & $7,378.4$ \\
Of which: Family labor cost & $2,052.4$ & $1,325.3$ \\
3. Gross margin & $2,666.8$ & $2,548.7$ \\
4. Total fixed costs & $1,912.8$ & $2,042.9$ \\
5. Total costs & $10,664.0$ & $9,421.3$ \\
6. Net return & 754.0 & 505.8 \\
7. Net return to family labor (NRL) & $2,806.4$ & $1,831.1$ \\
8. Net return to labor and fodder & $5,106.2$ & $3,992.9$ \\
\hline
\end{tabular}

Note: To calculate the value of above items, a number of family inputs (i.e. corn meals, cultivated grass, labor) were supposed to be purchased at market prices.

Source: Survey, 1999

Farmers could benefit from raising a cow, but net return was only moderate. On average, farmers received about $0.5-0.8$ million VND of net return within a year. However, dairy-farming activities occurred everyday and most of them were done by family laborers. Therefore, if adding family labor to net return (measured as '000 VND in a year), the indicator became 1.8 million VND and 2.8 million VND in Hatay and Hanoi, 
respectively. Moreover, most of the farmers in the study areas cultivated grass or collected it from outside, so their actual benefit from raising cow was quite high (i.e. it reached around 4 or 5 million VND in a year).

\section{FACTORS AFFECTING MILK OUTPUT}

\section{Quantitative analysis}

To quantify factors affecting milk output, the Cobb-Douglass production function was estimated by using SPSS software. The specification and expected results of the model were already presented in the part of methodology. After multicollinearity and heteroscedasticity tested, the function was estimated by WLS procedure with following outcomes:

$$
\begin{aligned}
& L n Y=3.48+0.2 \mathrm{LnCo}+0.15 \mathrm{LnFo}+0.19 \mathrm{LnLa}+0.1 \mathrm{LnEd}+0.05 \mathrm{LnEx} \\
& \begin{array}{lllll}
(6.741) & \text { (4.003) (2.539) (2.827) (2.278) }
\end{array} \\
& +0.48 \mathrm{LnFs}+0.13 \mathrm{LnBr}-0.07 \mathrm{D} \\
& \begin{array}{lll}
(7.129) \quad(2.654) \quad(-1.864)
\end{array}
\end{aligned}
$$

$\mathrm{F}-$ statistic $(8,81)=33.9$ with $\mathrm{p}<0.001$, adjusted $\mathrm{R}$ square $=0.747$

Note: Numbers in parenthesis are t-ratios

Results from regression analysis indicated that signs of the variables' coefficients were consistent with underlined expectations of the model. With the exception of dummy, all coefficients of the remainder variables were found to be positive and significant at 99 or 95 percent of confidence suggesting that farmers could still increase their milk output by additional use of inputs. The coefficient of dummy variable showed difference in milk output between households located in Hanoi and Hatay. Negative sign of the variable represented additional average output gained by Hatay households as compared to Hanoi farmers, holding the inputs constant. This difference was significant at 93.4 percent of confidence.

\section{Optimization of input use}

To evaluate efficiency of input use, farmers were assumed to be profit maximizers. Under profit maximizing assumptions, optimum level of input use will be at a point where marginal value of product of an input is equal to its price. Based on the formula, assessment of input use efficiency at mean level revealed that labor was slightly under-used, whereas concentrates and fodder were over utilized at the given prices of milk and respective inputs. This means that it was impossible for the farmers to increase their profits by using more feed (Note that their milk outputs can increase, but their profits might not). However, feed was not used solely for milk production but for the body maintenance and the growth of fetus. In the context of this study, the authors could not determine how much feed was needed to maintain a cow and to feed the fetus. However, it could be extrapolated that if over 49 percent and over 35 percent of the amount of concentrate and fodder, respectively are used for the body maintenance and the development of fetus, it is worth investing more feed *

* A milk cow having the weight of $400 \mathrm{~kg}$, producing $10 \mathrm{~kg}$ of milk per day and being in 6 months pregnant should be fed 4.0 feed unit for body maintenance, 5.0 feed unit for milk production and 0.6 feed unit for fetus feeding (Thuong,1998). 


\section{Constraints on dairy farming in the study areas}

Incident of diseases is the largest constraint for farm households in the study areas. Commonly, raising dairy cows needs high initial capital investment, so cows are said to be the whole assets of farmers. Whereas cows are very sensitive to changes of external environment, any sudden change can also affect their health and milk yields. High risk in business makes farmers hesitate to enter or expand their dairy farm sizes. Besides, the veterinary network in the region was not good enough to prevent and to diagnose many kinds of diseases in time. This feature increased the risk of raising cow.

Difference in prices of raw milk between two locations has been unsatisfactory to Hatay farmers. The survey revealed that there was not much difference in price of inputs between locations, but milk price in Hatay was about $300 \mathrm{VND} / \mathrm{kg}$ (or 10 percent) lower than that of Hanoi. Therefore, the price policy has not encouraged Hatay farmers to enter or to extend dairy farming.

Lack of fodder, especially in winter season is another constraint for Hanoi farm households. Land size $4,176 \mathrm{~m}^{2}$ was considered to be small for a household raising dairy cows. Because of limited land, many households do not want to allocate their land to grow grass. Further, the task of fodder zoning has not been intervened well by communes' leaders (local leaders). Crop fields and fodder blocks were interspersed haphazardly in the villages. The fodder blocks were alleged to harbor crop pests that attacked the crops in the adjacent fields. This often raised conflicts due to heavier sabotage by rats and insects between neighbors having their crop and fodder fields located adjacently. The situation made dairy farmers hesitate to cultivate grass. Also, average homestead land of a household which included areas of houses, yard, cow shed, etc. was only $180 \mathrm{~m}^{2}$. Limitation of homestead land was one of the reasons causing environmental pollution in the settlement areas.

When farmers start to establish their dairy farms, they want to borrow money from formal sources in the hope of obtaining long term and low-interest loans. However, they have to face a complex lending procedure with the requirements of many documents and approvals. The situation forced some farmers to borrow from informal sources at high interest rate.

Lack of adequate and regular training opportunities for farmers to prepare them for handling improved breeds and modern husbandry practices successfully, is another constraint. Many farmers did not possess enough knowledge of prevention and control of cow disease, thus frequent outbreaks of diseases resulted into losses to dairy farmers.

Although achieving remarkable progress in the improvement of the milk collection network, there are still some communes in the region not having any milk collection station. Farmers have to deliver raw milk by themselves to the milk processing factory or other buying points, which are located very far from their houses. High transportation cost and unstable prices did not encourage them to enter and expand dairy farms.

\section{CONCLUSION AND RECOMMENDATION}

\section{Conclusion}

The farming system in the study area had commercial production oriented with close integration of dairy and crop components. Dairy component did not compete in space 
with rice-the main crop in the region, but contributed to increasing productivity by supplying manure to the rice field. Other plants such as corn, cassava, and grass were largely cultivated to provide feed for rearing cows, so the competition for land among them was obvious and necessary.

Based on underlying quality standards, raising an F2 3/4 blood of HF was better in terms of benefit than rearing others. In the case of poorer raising skills and limited capital, dairy farmers could choose cows having lower percentage of HF blood in crossbreed (i.e. F1 1/2 of HF blood cow). They might generate moderate net return to the farmer.

The fear about incidence of disease, lack of capital and fodder were main reasons behind the low cow population in the study area. Thus, to develop cow herd in the region, it is first necessary to solve these constraints.

There was lack of cooperation among dairy farmers. For both locations, most farmers did not organize themselves into any kind of co-operative (i.e. credit group, or producer group). As a result, they had less bargaining power.

The price of raw milk was predetermined by buyers according to given quality standards. Thus, the best way to get higher price is the improvement of milk quality. There was still a room for dairy farmers to receive higher price by this way.

Given the small herd situation, an increase in milk output from the region must rely heavily on raising cows with high percentage of $\mathrm{HF}$ blood (i.e. $3 / 4 \mathrm{HF}$ blood cow), and on improving knowledge in husbandry techniques of dairy farmers.

\section{Recommendation}

1. Training courses on husbandry should be held regularly and efficiently. Especially, new farmers should be trained before they start operating their dairy farms. In addition, improvement of veterinary and milk collection networks at the raising zones is also very necessary.

2. Local leaders should pay attention on zoning concentrated grass production areas in order to limit the negative impact on crop fields and to contribute to providing enough fodder for feeding.

3. Dairy farmers should be encouraged to organize themselves into kinds of co-operation such as credit groups, marketing groups, and producer groups to help each other and have more bargaining powers.

4. Processing the waste of dairy farms (i.e. urine, manure) should be taken into account by both authorities and dairy farmers. The government should partially support budget to the households applying technology of biogas manufacturing from the waste of dairy farm, so that pollution is prevented effectively.

5. If the prices of raw milk and respective inputs are unchanged, the major productivity improvement should rely heavily on raising high percentage $\mathrm{HF}$ blood cows (i.e. F2 cows). However, institutional interventions are very essential for rationalizing the system of milk pricing in the region. The government should seriously pay attention to price policy.

6. Many farmers in the study area had poor access to credit. Therefore, to improve breed and expand herd size, providing a reasonable credit system (longer term and low interest loan, simplification of lending procedure) is also very necessary. 


\section{REFERENCES}

Agricultural and Forestry Extension Center 1997 Draft of Project on Developing Cow Herd in Vietnam. Hanoi: Ministry of Agriculture and Rural Development. (in Vietnamese)

Agricultural and Forestry Extension Center 2002 Report on Situation of Dairy Production in 2002. Hanoi: Ministry of Agriculture and Rural Development. (in Vietnamese)

Binnie, SMEC, AACM and Delft 1995 Red River Delta Master Plan. Vol. 2. Hanoi: Statistical Publishing House.

Chantalakhana, C and P. Skunmun 2001 Dairy Development in Thailand and a Case Study on Environmental Impacts of Peri-urban Dairy Colonies Part I. Smallholder Dairy Development. Internet, http://www.ssdairy.org/Programme/html/ch12.htm

General Statistical Office 1999 Statistical Yearbook 1998. Hanoi: Statistical Publishing House.

General Statistical Office 2000 Statistical Yearbook 1999. Hanoi: Statistical Publishing House.

Institution of Strategical Development 1996 Orientation of Industrialization and Modernization in Vietnam toward the year 2020. Hanoi: Ministry of Plan and Investment. (in Vietnamese).

Lich, L. B and Tuyen, D. K. 2002 Report on "Situation and Direction of Dairy Development in Vietnam from 2002 to 2010". Paper was presented at workshop on national dairy raising, Ho Chi Minh city, January $3^{\text {rd }} 2002$.

Thuong, N. V. 1998 Technique of Cow Raising at Farm Household Level. Hanoi: Agricultural Publisher. (in Vietnamese).

Vang, V. D. 1998 "Some Research Results and Advanced Technologies Could Be Transferred to Mass Production". Journal of Market and Price.1 (March): 181-189. 